\title{
Estimating Population Densities of Black-TaIled Prairie Dogs
}

\author{
KIETH E. SEVERSON $\downarrow$ USDA FOREST SERVICE $\downarrow$ ROCKY MOUNTAIN STATION \\ SCHOOL OF MINES CAMPUS $\uparrow$ RAPID CITY, SD \\ AND \\ GLENN E. Plumb $\downarrow$ NATIONAL PARK SERVICE \\ BADLANDS NATIONAL PARK $\downarrow$ INTERIOR, SD
}

\section{$\uparrow \quad$ BACKGROUND}

The recent black-footed ferret reintroduction into the Conata Basin area of westcentral South Dakota has prompted managers of USDA Forest Service, Buffalo Gap National Grasslands and National Park Service, Badlands National Park, to reassess methods of determining population size of black-tailed prairie dogs Cynomys ludovicianus. Most agencies are currently relying on a protocol developed by Biggins et al. (1993) to assess black-fonted ferret habitat, a section of which deals with prey abundance. The protocol is based on population estimates derived from counting the number of active burrows. The justification for this was a set of unpublished data that reported fair and good relationships between counts of active burrows and black-and white-tailed prairie dogs C. leucurus, respectively (Biggins et al. 1993). While there is no other correlative information relative to active burrows, Powell et al. (1994) suggested that counts of active burrows alone may not be a reliable indicator of black-tailed prairie dog populations. Menkens et al. (1988) examined relationships between populations determined by mark-recapture and total burrow counts. They reported that whitetailed prairie dog density was not significantly related to burrow density and was not a useful predictor of population density. However, Fagerstone and Biggins (1986) and Menkens et al. (1990) reported high correlation coefficients when comparing visual counts of white-tailed prairie dogs with mark-recapture densities. The purpose of this study was to examine relationships among population estimates from mark-recapture techniques with visual counts, active burrow counts, and total burrow counts derived by ground and aerial surveys all within the same experimental design.

\section{$\downarrow \quad$ STUDY AREA}

The study was conducted in the Conata Basin area of west-central South Dakota on lands administered by both USDA Forest Service, Buffalo Gap National Grasslands, and the National Park Service, Badlands National Park. Climate is semiarid with an average $(40 \mathrm{yr})$ annual precipitation of $39.9 \mathrm{~cm}$, most of which falls during the growing season in locally severe thunderstorms. Mean annual temperature is $10.3^{\circ} \mathrm{C}$ and monthly means range from $-4.6^{\circ} \mathrm{C}$ in January to $25.5^{\circ} \mathrm{C}$ in July (NOAA 1993). Vegetation is mixed prairie dominated by western wheatgrass Agropyron smithii, buffalograss Buchloe dactyloides, and blue grama Bouteloua gracilis.

\section{$\downarrow \quad$ METHODS}

Twelve prairie dog colonies were selected in 1993; eight were located in Buffalo Gap National Grasslands and four were located in Badlands National Park. A $200 \mathrm{~m} \times 200 \mathrm{~m}$ macroplot (4 
hectares) was established on each of the 12 colonies. A mark-recapture grid was placed within each of the twelve macroplots and numbered wooden stakes were placed at $16.7 \mathrm{~m}$ in a $10 \times 10$ grid in the middle of the macroplot which left a buffer strip of $25 \mathrm{~m}$ around the trap grid. Staked locations were prebaited with a commercial horse feed composed of corn, oats, barley and molasses. The following day, live traps, $61 \mathrm{~cm} \times 23 \mathrm{~cm} \times 20 \mathrm{~cm}$, were placed at each stake, left open, and prebaited again. Traps were set on the third day and animals were trapped for 4-5 consecutive mornings (until an estimated equilibrium population density was reached). Traps were set from 0700 to $0800 \mathrm{hrs}$ and left open for about $4 \mathrm{hrs}$. Animals were marked with green acrylic paint and released. All prairie dog shooting on colonies within National Grasslands was prohibited during trapping and visual counting activities to insure population closure. Trapping activities were conducted from late June through August. The program CAPTURE (Rexstad and Burnham 1991) was used to estimate density. Markrecapture provides an unbiased estimate of population density (Seber 1986). Visual counting, using $7 \times 35 \mathrm{~mm}$ binoculars, was done immediately before or within one week after trapping, for three consecutive days. Counts were made from a 3-m high observation platform placed on the southeast corner of the macroplot. Plot boundaries were delineated using fluorescent orange painted stakes. All prairie dogs on each macroplot were counted 4 consecutive times. Observers entered the blind about $0700 \mathrm{hrs}$, waited $30 \mathrm{~min}$ before beginning the first count and $15 \mathrm{~min}$ between counts. Burrow counts were conducted on all twelve macroplots by strip transect ground counts (sensu Biggins et al. 1993). Regression and correlation analyses were conducted using population estimates from markrecapture as the dependent variable against the following independent variables: Maximum visual counts, mean visual counts, active mounded burrows from ground counts, total active burrows (mounded and unmounded) from ground counts, and total burrows from ground counts (Statistical Graphics Corporation 1989). Paired T-tests were used for all between year comparisons with data from only those 10 colonies with paired data (Norusis 1990). All data were transformed to prairie dogs or burrows per ha which were used in the analyses. Differences in slopes (b) between years were examined using multivariate analysis of variance (MANOVA)(SAS Institute, 1988). All statistical inferences were made at $\alpha=0.05$.

\section{$\downarrow \quad$ RESULTS}

\section{VISUAL COUNTS}

Correlations between visual counts and populations estimated via mark-recapture were clearly better than any of the methods involving burrow counts. Within visual counts, maximum counts rather than mean counts resulted in better correlations based on lower standard errors and higher coefficients of determination $\left(R^{2}\right)$. In 1993, mean count relationships were not significant for either linear or exponential models. Slopes (b), indicative of the probability distribution of population density as a function of visual counts, were similar between years for mean counts (MANOVA, $F=2.74,1,20 \mathrm{df}, \mathrm{P}=0.113$ ) and for maximum counts (MANOVA, $F=3.39,1,20 \mathrm{df}$, $\mathrm{P}=.081$ ), hence years were pooled. Although $\mathrm{b}$ values appear to be nearly twice as great in 1994 as compared to 1993, variability among counts between years precluded detection of significance. There were fewer prairie dogs counted in 1994, relative to the estimated population, than in 1993. There were also two colonies where the number counted exceeded the estimated population in 1993, but all counts were less than the estimated in 1994 . Linear and exponential models for maximum counts exhibited few differences. Standard errors, expressed as a percentage of the mean of the $\mathrm{Y}$ variables, were slightly lower for exponential forms $(0.3,0.6$, and $3.1 \%$, for 1993,1994 , and pooled data, respectively) and the $\mathrm{R}^{2} \mathrm{~s}$ slightly higher for linear forms except for 1993. Linear models, in general, appear best for predictive analyses because the intercept is closer to 0, at least for 1994 and pooled forms. Further, exponential models would yield unrealistic projections if visual maximum counts were high (e.g., >25/ha). The 1994 linear model is the most precise model; the $\mathrm{R}^{2}$ indicates that over $77 \%$ of the variation in the population can be accounted for by maximum visual counts, which is higher than either the 1993 or pooled forms. The standard error of the regression, again expressed as a percentage of the mean of the $\mathrm{Y}$ variables, is lower for the 1994 linear model as compared to the pooled linear model (28.9 and $33.9 \%$, respectively) but only slightly larger than for the 1993 linear model $(26.9 \%)$. From a biological standpoint, however, the pooled linear model would be best for predictive purposes. This accounts for year-to-year variations, although in a limited sense because it includes only 
2 years data. There were differences in population structure between years. Although the mean number of animals trapped per colony was similar (49 in 1993 and 51 in 1994; $t=-0.20,9 \mathrm{df}, \mathrm{P}=0.847$ ), adults made up $70 \%$ of the total in 1993 and only $35 \%$ in 1994. There may be differences in sightability between adults and juveniles or there may be differences in behavior that result from such differences in population structure that affect counts and therefore the population/count relationships.

\section{BURROW COUNTS}

There was no correlation between population estimates and burrow counts, active or total, from ground transects. Slopes (b) were not different from 0 ( $\mathrm{P}$ ranging from 0.34 to 0.96 ) (Table 1) using the linear model. Although data are not presented, no improvement was noted with exponential forms. Examination of scatter plots did not reveal any patterns that could be attributed to 'old' or 'new'colonies or whether or not the colony was subjected to hunting. Our findings confirm those of Powell et al. (1994) but are in contrast to those of Biggins et al. (1993) who reported $R^{2}$ of $88.4 \%$ using active burrow counts on white-tailed prairie dog colonies and $42.5 \%$ on black-tail colonies.

\section{MANAGEMENT IMPLICATIONS}

Burrow counts, active mounded, total active, or total burrows, should not be used to estimate black-tailed prairie dog numbers. Neither should they be used as an index to populations. The absence of any significant relationships between burrow counts and numbers determined by markrecapture methods over a two-year period is sufficient evidence that the reliability of the method is not consistent. Visual counts, a direct form of assessing populations, have consistently yielded significant relationships with populations estimated via mark- recapture techniques in this and other studies (Fagerstone and Biggins 1986, Menkens et al. 1990) and with populations determined by trapping all individuals within the colony (Knowles 1986). The best visual count estimator to use is the maximum count rather than the mean number counted, as noted in this study and by Fagerstone and Biggins (1986). Are these resultant models good enough to be used in a predictive sense; that is,can they be used to compare populations among colonies, areas, and years? Menkens et al. (1990) stated that if detailed data on prairie dog populations were required, (i.e., population dynamics) a better technique, such as mark- recapture, must be used. A disadvantage of mark-recapture is that the technique is labor and time intensive and, as a result, too expensive for extensive surveys. They further recommended, however, that visual counts were acceptable for evaluations of ferret reintroduction sites and for comparing prairie dog population numbers between years. We concur with this assessment while recognizing that visual count models are also subject to error as indicated by the $\mathrm{R}^{2}$, standard error, and confidence limits. The reliability of the model could likely be improved if additional years data were obtained.

\section{LiTERATURE CITED}

Biggins, Dean E., Brian J. Miller, Louis R. Hanebury, Bob Oakleaf, Adrian H. Farmer, Ron Crete, and Arnold Dood. 1993. A technique for evaluating blackfooted ferret habitat, p. 73-88. In: Oldemeyer, John L., Dean E. Biggins, and Brian J. Miller, eds. Proceedings of the symposium on the management of prairie dog complexes for the reintroduction of the black-footed ferret. Biological Rep. 13. U.S. Dept. of Interior, Fish and Wildlife Service, Washington, D.C.

Fagerstone, Kathleen A. and Dean E. Biggins. 1986. Comparison of capture-recapture and visual count indices of prairie dog densities in black-footed ferret habitat. Great Basin Naturalist Memoirs 8:94-98.

Knowles, Craig J. 1982. Habitat affinity, populations and control of black-footed prairie dogs on the Charles M. Russell National Wildlife Refuge. PhD Diss., Univ. of Montana, Missoula.

Menkens, George E. Jr, Dean E. Biggins, and Stanley H. Anderson. 1990. Visual counts as an index of white-tailed prairie dog density. Wildl. Soc. Bull. 83(3):290-296. 
, Brian J. Miller, and Stanley H. Anderson. 1988. White-tailed prairie dog ecology in Wyoming, p. 34-38. In: Eighth Great Plains Wildlife Damage Control Workshop Proceedings. USDA Forest Service, Gen. Tech. Rep. RM-154. Rocky Mountain Forest and Range Experiment Station, Fort Collins, CO.

NOAA. 1993. Climatological Data Annual Summary, Vol. 8, No. 13. National Oceanic and Atmospheric Administration, National Climatic Data Center, Asheville, NC.

Norusis, Marija J. 1990. SPSS/PC + Statistics 4.0 for the IBM PC/XT and PS/2. SPSS, Inc., Chicago, IL.

Powell, Kenneth L., Robert J. Robel, Kenneth E. Kemp, and M. Duane Nellis. 1994. Aboveground counts of black-tailed prairie dogs: Temporal nature and relationship to burrow entrance density. J. Wildl. Manage. $58(2): 361-366$.
Rexstad, Eric and Kenneth Burnham. 1991. User's guide for interactive program CAPTURE. Colo. Coop. Fish and Wildl. Unit, Colo. State Univ., Fort Collins.

SAS Institute. 1988. SAS/STAT user's guide. Release 6.03 ed. SAS Inst., Cary, NC.

Seber, G.A.F. 1986. A review of estimating animal abundance. Biometrics 42:267-292.

Statistical Graphic Corporation. 1989. STATGRAPHICS Statistical Graphics System, Version 4.0, Statistical Graphics Corporation, Rockville, MD. 